\title{
Short Somatic Mutation
}

National Cancer Institute

\section{Source}

National Cancer Institute. Short Somatic Mutation. NCI Thesaurus. Code C157604.

Single nucleotide polymorphisms (SNPs) or short nucleotide insertions (ins), deletions

(del) or indels that originate in cells that are not destined to become gametes and are not passed on to progeny. 